НАУКОВИЙ ВІСНИК

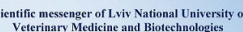

(20)

in

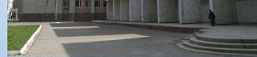

СЕРЯ: ВЕТЕРИНАРН НАУКИ
Науковий вісник Дьвівського національного університету ветеринарної медицини та біотехнологій імені С.3. Гжицького. Серія: Ветеринарні науки

Scientific Messenger of Lviv National University of Veterinary Medicine and Biotechnologies. Series: Veterinary sciences

UDC 636.09:614.3

\title{
Monitoring of compliance of quality and safety of sunflower honey with the requirements of the national standard
}

\author{
H. A. Skrypka ${ }^{1}$, M. S. Khimych ${ }^{1}$, V. Z. Salata ${ }^{2}$, O. V. Naidich ${ }^{1}$, O. M. Gorobei ${ }^{1}$, T. S. Matviishyn ${ }^{2}$ \\ ${ }^{1}$ Odessa State Agrarian University, Odessa, Ukraine \\ ${ }^{2}$ Stepan Gzhytskyi National University of Veterinary Medicine and Biotechnologies Lviv, Ukraine
}

\section{Article info}

Received 09.08.2021

Received in revised form 09.09.2021

Accepted 10.09.2021

Odessa State Agrarian University, Panteleymonyvska Str., 13, Odessa 65012, Ukraine.

Tel.: +38-067-799-21-13

E-mail:khimichms@gmail.com

Stepan Gzhytskyi National University of Veterinary Medicine and Biotechnologies Lviv, Pekarska Str., 50, Lviv, 79010, Ukraine.

Tel.: +38-067-728-89-33

E-mail: salatavolod@ukr.net
Skrypka, H. A., Khimych, M. S., Salata, V. Z., Naidich, O. V., Gorobei, O. M., \& Matviishyn, T. S. (2021). Monitoring of compliance of quality and safety of sunflower honey with the requirements of the national standard. Scientific Messenger of Lviv National University of Veterinary Medicine and Biotechnologies. Series: Veterinary sciences, 23(103), 162-167. doi: 10.32718/nvlvet10323

Honey natural is one of unique booties of beekeeping. It is not only sweet addition to the ration but also valuable product that contains many important substances, in particular vitamins, micro-macronutrients, enzymes, irreplaceable amino acids and other, that must be in the food ration of everybody. For this reason for today honey is one of products, that occupies the not last place among commodity turnover. It touches not only markets but also trade network of shops and supermarkets. In recent year many producers that buy up honey on apiaries appeared in a trade network, buying honey in apiaries, package and will realize. Such honey needs careful veterinary control in relation to quality and unconcern, in fact he is one of food products, that sufficiently often yields to falsification, and to the consumer, it is almost impossible, independently to distinguish a quality product from an imitation. Therefore the aim of our research was to analyse accordance of indexes of quality and unconcern of honey natural of different producers, that will be realized in the trade network of city in relation to accordance to DSTU 4497:2005 "Natural honey. Specification". The material of our research was samples of sunflower honey from several domestic producers, selected in the trade network. The research was conducted on the basis of Multidisciplinary Laboratory of Veterinary Medicine (Faculty of Veterinary Medicine and Biotecnologies of Odessa State Agrarian University) and on the basis of the laboratory of Department of Veterinary-Sanitary Inspection (Stepan Gzhytskyi National University of Veterinary Medicine and Biotechnologies, Lviv). Sampling, organoleptic and physicochemical analysis of natural honey, as well as determination of radiological parameters were performed in accordance with DSTU 4497:2005. According to the results of the analysis of the labeling, it is established that the packaging of all investigated products contains the basic production and consumer information in accordance with Article 6 of the Law of Ukraine "On information for consumers about food". However, the labels of all test samples do not contain separate information provided by the requirements of DSTU 4497:2005 on labeling, namely: the labels of samples №№ 1 and 3 do not indicate the grade of honey, vitamin content and storage temperature of honey, and the expiration date from the date of packaging, not the day of manufacture; on the label of the sample № 2 - the date of packing is not indicated. The study of organoleptic, physicochemical and radiological parameters of sunflower honey samples demonstrates their compliance with the requirements of the regulated DSTU 4497:2005 "Natural honey. Specification".

Key words: veterinary and sanitary inspection, honey, quality, safety.

\section{Моніторинг відповідності якості та безпечності соняшникового меду вимогам національного стандарту}

\author{
Г. А. Скрипка ${ }^{1}$, М. С. Хімич ${ }^{1}$, В. 3. Салата ${ }^{2}$, О. В. Найдіч ${ }^{1}$, О. М. Горобей${ }^{1}$, Т. С. Матвіїшин ${ }^{2}$ \\ ${ }^{1}$ Одеський державний аграрний університет, м. Одеса, Украӥна \\ ${ }^{2}$ Львівський національний університет ветеринарної медицини та біотехнологій імені С. 3. Гжсииького, м. Львів,
}


Мед натуральний є одним з унікальних видобутків бджільництва. Це не тільки солодка добавка до раціону, а й цінний продукт, цио містить багато важливих речовин, зокрема вітамінів, мікро-макроелементів, ферментів, незамінних амінокислот та ін., які повинні бути в харчовому раціоні кожної людини. Саме тому на сьогодні мед є одним з продуктів, який займає не останнє місие серед товарообігу. Це стосується не тільки ринків, а й торговельної мережі магазинів та супермаркетів. В останні роки у торговельній мережі з'явилося багато виробників, які скуповують мед на пасіках, купажуть його, фасують та реалізують. Такий мед потребує ретельного ветеринарного контролю щодо якості та безпечності, адже він є одним з харчових продуктів, який доволі часто піддається фальсифікації, а споживачу майже неможливо самостійно відрізнити якісний продукт від підробки. Тому метою нашого дослідження було проаналізувати відповідність показників якості та безпечності меду натурального різних виробників, який реалізується у торгівельній мережі міста щуодо відповідності до ДСТУ 4497:2005 "Мед натуральний. Загальні технічні умови”. Матеріалом наших досліджень були зразки соняцникового меду кількох вітчизняних виробників, відібрані у торговій мережі. Дослідження проводили на базі багатопрофільної лабораторії факультету ветеринарної медицини Одеського державного аграрного університету та лабораторії кафедри ветеринарно-санітарного інспектування Львівського національного університету ветеринарної медицини та біотехнологій імені С. З. Гжицького. Відбір проб, органолептичний та фізико-хімічний аналіз меду натурального, а також визначення радіологічних показників проводили згідно з ДСТУ 4497:2005. За результатами аналізу маркування встановлено, щчо на пакуванні всіх досліджених виробів зазначено основну виробничу і споживчу інформацію відповідно до ст. 6 Закону Украйни “Про інформацію для спожсвачів щөодо харчових продуктів". Але на етикетках всіх дослідних зразків відсутня окрема інформація, передбачена вимогами ДСТУ 4497:2005 щодо маркування, а саме: на етикетках зразків № 1 і 3 не зазначено татунку меду, вмісту вітамінів і температури зберігання меду, а термін придатності вказано від дати фасування, а не дня виготовлення; на етикетці зразка № 2 - не позначено дату фасування. Дослідження органолептичних, фізико-хімічних і радіологічних показників зразків соняшникового меду демонструє їх відповідність вимогам, регламентованих ДСТУ 4497:2005 “Мед натуральний. Загальні технічні умови”.

Ключові слова: ветеринарно-санітарне інспектування, мед, якість, безпечність.

\section{Вступ}

Бджолиний мед - цінний харчовий продукт, який має високі поживні, лікувальні та профілактичні властивості. Хімічний склад меду дуже складний і значно варіює залежно від його видового походження, умов збору і зберігання, зрілості тощо. Своєю чергою значна варіабельність хімічного складу сприяє доволі значній мінливості фізико-хімічних показників меду, тому моніторинг саме цих показників є невід'ємною ланкою визначення його натуральності та доброякісності (Khimych et al., 2018; Golda \& Jefimov, 2019; Dudar, 2020; Korbych, 2020; Blanc et al., 2021).

Водночас не менш важливим показником є безпечність меду, яка напряму залежить від рівня техногенного навантаження зони медозбору (Vishchur et al., 2019; Piven et al., 2020).

В Україні якість і безпечність меду регламентується низкою документів, основним 3 яких $є$ ДСТУ 4497:2005 “Мед натуральний. Технічні умови” (Ratiu et al., 2020; Kravchuk, 2021; Lazarjeva et al., 2021).

3 огляду на те, що Україна є одним зі світових лідерів виробництва меду, на вітчизняному ринку присутня доволі значна кількість операторів, які представляють свій продукт у торговій мережі. Встановлення якості й безпечності представленого на ринку меду $є$ вкрай важливим, особливо 3 огляду на його високі поживні та лікувальні властивості (Elamine et al., 2018; Kravchenko \& Izhboldina, 2019; Postojenko et al., 2019; Lazareva et al., 2021).

Тому питання належного контролю якості та безпечності меду натурального є актуальним.

Мета та завдання дослідження. Враховуючи вищевикладене, метою нашого дослідження було проаналізувати показники якості та безпечності соняшникового меду різних вітчизняних виробників на відповідність ДСТУ 4497:2005 “Мед натуральний. Технічні умови" з виконанням таких завдань:
- проаналізувати відповідність маркування;

- провести аналіз органолептичних показників;

- провести аналіз основних фізико-хімічних показників;

- провести аналіз окремих показників безпечності (радіологічні показники).

\section{Матеріал і методи досліджень}

Об'єктом досліджень слугували зразки соняшникового меду вітчизняних виробників: Зразок № 1, Зразок № 2 і Зразок № 3, відібрані шляхом контрольної закупки у торговельній мережі міст Одеси (“АТБ”, “Копійка”) та Львова (“Сільпо”).

Експериментальні дослідження проводили на базі багатопрофільної лабораторії факультету ветеринарної медицини Одеського державного аграрного університету та лабораторії кафедри ветеринарно-санітарного інспектування Львівського національного університету ветеринарної медицини та біотехнологій імені С. 3. Гжицького. Аналіз маркування меду проводили відповідно до Закону України "Про інформацію для споживачів щодо харчових продуктів” (2019) та ДСТУ 4497:2005; відбір зразків меду, органолептичні, фізико-хімічні та радіологічні дослідження проводили згідно 3 ДСТУ 4497:2005, Методичних рекомендацій щодо проведення ветеринарно-санітарної експертизи меду та продуктів бджільництва (2012) і СОУ-01.25-37371:2005 "Ветеринарно-санітарна експертиза меду та продуктів бджільництва”. Для визначення масової частки вологи використовували рефрактомет Atago HHR-2N, загальну кислотність визначали за допомогою рН-метру НІ 2020-02. Радіонукліди ( ${ }^{137} \mathrm{Cs}$, ${ }^{90} \mathrm{Sr}$ ) визначали за допомогою $\beta$ - $\gamma$-спектрометра СЕБ01 з використанням програмного забезпечення Akwin. 


\section{Результати дослідження}

На першому етапі наших досліджень провели аналіз маркування дослідних зразків меду (табл. 1).

Встановлено, що маркування дослідних зразків соняшникового меду відповідає Закону України “Про інформацію для споживачів щодо харчових продуктів” (2019). Однак у нас виникли зауваження щодо якості та вичерпності інформації, наданої на етикетках дослідних зразків згідно з ДСТУ 4497:2005.

Таблиця 1

Аналіз маркування меду соняшникового

\begin{tabular}{|c|c|c|c|}
\hline \multirow{2}{*}{ Дослідний показник } & \multicolumn{3}{|c|}{ Зразки } \\
\hline & 1 & 2 & 3 \\
\hline $\begin{array}{l}\text { Документ, відповідно до } \\
\text { якого продукт вироблено }\end{array}$ & ДСТУ 4497:2005 & ДСТУ 4497:2005 & ДСТУ 4497:2005 \\
\hline Гатунок & - & Перший гатунок & - \\
\hline Перелік інгредієнтів & $\begin{array}{l}\text { Мед натуральний } \\
\text { соняшниковий }\end{array}$ & Мед натуральний соняшниковий & $\begin{array}{c}\text { Мед натуральний соняшни- } \\
\text { ковий }\end{array}$ \\
\hline $\begin{array}{l}\text { Харчова та енергетична } \\
\text { цінність } 100 \text { г меду }\end{array}$ & $\begin{array}{c}\text { Білки 0,8 г } \\
\text { Вуглеводи } 748 \text { г } \\
1313,8 \text { кДж (314 ккал) }\end{array}$ & $\begin{array}{c}\text { Білки 0,8 г } \\
\text { Вуглеводи 74,8 мг } \\
\text { Вітаміни: В1 - 0,01 мг } \\
\text { В2 - 0,03 г, РP - 0,2 мг } \\
\text { С - 2 мг } \\
314 \text { ккал } \\
\end{array}$ & $\begin{array}{c}\text { Білки } 0,8 \text { г } \\
\text { Вуглеводи 74,8 мг } \\
1313,8 \text { кДж (314 ккал) }\end{array}$ \\
\hline $\begin{array}{l}\text { Умови зберігання і } \\
\text { термін придатності }\end{array}$ & $\begin{array}{c}\text { Зберігати в } \\
\text { приміщеннях, } \\
\text { захищених від прямих } \\
\text { сонячних променів. } \\
\text { Строк придатності: } 2 \\
\text { роки з дати фасування } \\
\text { Дата фасування: } \\
22.09 .2019 \\
\end{array}$ & $\begin{array}{c}\text { Зберігати в приміщеннях, } \\
\text { захищених від прямих сонячних } \\
\text { променів при температурі не } \\
\text { більше } 25^{\circ} \mathrm{C} \\
\text { Строк придатності - } 2 \text { роки з } \\
\text { дати медозбору Дата медозбору } \\
14.08 .2020 \text { p. } \\
\text { Придатний до } 14.08 .2022 \mathrm{p} .\end{array}$ & $\begin{array}{c}\text { Зберігати в приміщеннях, } \\
\text { захищених від прямих } \\
\text { сонячних променів. } \\
\text { Строк придатності: два роки } \\
\text { з дати фасування } \\
\text { Дата фасування: } 31.07 .2020\end{array}$ \\
\hline Рік збору & Рік збору 2019 & - & Рік збору 2020 \\
\hline Назва та адреса виробника & + & + & + \\
\hline $\begin{array}{l}\text { Штрих-код ЕAN } \\
\text { продукції згідно } \\
\text { ДСТУ } 3145\end{array}$ & + & + & + \\
\hline Додаткові позначки & $\begin{array}{c}\text { Не містить ГМО та } \\
\text { антибіотики } \\
\text { Вага нетто }-250 \text { г } \\
\text { Вага брутто }-460 \text { г }\end{array}$ & $\begin{array}{c}\text { Піддається кристалізації } \\
\text { Хворим на алергію перед } \\
\text { споживанням слід порадитися } 3 \\
\text { лікарем } \\
\text { Маса нетто: } 250 \text { г } \pm 2 \text { г }\end{array}$ & $\begin{array}{c}\text { Продукт може викликати } \\
\text { алергію } \\
\text { Не містить ГМО та } \\
\text { антибіотики } \\
\text { Може містити частку інших } \\
\text { сортів меду } \\
\text { Вага нетто }-250 \text { г } \\
\text { Вага брутто }-385 \text { г } \pm 5 \text { г }\end{array}$ \\
\hline
\end{tabular}

Так, згідно з вимогами ДСТУ 4497:2005, маркування меду повинно містити таку інформацію: назву та адресу виробника і місце виготовлення меду; назву продукції; гатунок (вищий або перший); рік збору меду та дату фасування; масу нетто; термін придатності до споживання; штрих-код EAN продукції; знак відповідності (для продукції, яка пройшла сертифікацію); харчову та енергетичну цінність згідно 3 даними додатку А до ДСТУ 4497:2005 (а саме: харчову та енергетичну цінність у 100 г меду; вміст білків, г; вуглеводів, г; та вітамінів, $\mathrm{M \Gamma ).}$

Встановлено, що етикетка зразка № 1 не містить повних даних щодо харчової та енергетичної цінності 100 г меду, а саме не зазначено вмісту вітамінів; щодо умов зберігання і термінів придатності - не зазначено температури зберігання меду; термін придатності вказано від дати фасування, а не дня виготовлення. Також на етикетці не зазначено гатунку меду i допустимих відхилень ваги фасованого продукту.
Зразок № 2 максимально відповідав вимогам ДСТУ 4497:2005 щодо маркування, але на етикетці не позначено дати фасування.

Маркування зразка № 3 також не відповідало вимогам ДСТУ 4497:2005, а саме на етикетці вітсутня інформація щодо гатунку меду, вмісту вітамінів, температури зберігання меду. Крім того, термін придатності меду вказано від дати фасування, а не дня медозбору. Також на етикетці не позначено допустимих відхилень об'єму фасованої продукції, проте позначено відхилення маси брутто, що не $\epsilon$ обов'язковою позначкою.

Надалі ми провели аналіз якості пакування дослідних зразків меду. Відібрані зразки були розфасовані у скляні банки - згідно з ГОСТ 5717, тара була закупорена герметично металевими кришками методом нагвинчування. Згідно 3 ДСТУ 4497:2005 допустимими відхиленнями об'єму фасованої продукції для окремих одиниць тари 0,25 дм $^{3}$ від номінальної кількості не повинні перевищувати 
значень, \%: \pm 4,0 \%. Встановлено, що пакування всіх досліджених зразків відповідало вимогам ДСТУ 4497:2005.

На другому етапі наших досліджень провели органолептичну оцінку зразків меду. За результатами дослідження кольору встановлено, що зразки соняшникового меду мали світло-жовте (№ 1 i 3) та яскраво-жовте (№ 2) забарвлення. Дослідження смаку встановили, що смак всіх зразків був приємним, солодким, без сторонніх присмаків, відчувалося подразнення слизової ротової порожнини. За визначення аромату встановлено, що всі дослідні зразки мали приємний, ніжний, яскраво виражений квітковий аромат без сторонніх запахів. Щодо консистенції зразків, то вона була щільною і шпатель у дослідні зразки занурювався під тиском. Кристалізація зразків соняшникового меду була дрібнозернистою. Ознак бродіння та механічних домішок не виявлено в жодному 3 досліджених зразків.

На третьому етапі наших досліджень визначали фізико-хімічні показники зразків меду: масову частку води, діастазне число, вміст інвертованого цукру, активну кислотність. Також було проведено якісну реакцію на наявність паді та пилковий аналіз (табл. 2).

Таблиця 2

Фізико-хімічні показники соняшникового меду $(\mathrm{M} \pm \mathrm{m}, \mathrm{n}=15)$

\begin{tabular}{|c|c|c|c|c|}
\hline \multirow{2}{*}{ Найменування показника } & \multirow{2}{*}{ Вимоги ДСТУ } & \multicolumn{3}{|c|}{ Дослідні зразки } \\
\hline & & № $1, \mathrm{n}=5$ & № $2, \mathrm{n}=5$ & № $3, \mathrm{n}=5$ \\
\hline Результат пилкового аналізу & $\begin{array}{c}\text { Наявність пилкових } \\
\text { зерен }\end{array}$ & Пилкові зерна & Пилкові зерна & Пилкові зерна \\
\hline Масова частка води, \%, не більше & 21,0 & $16,7 \pm 0,18$ & $17,2 \pm 0,24$ & $16,5 \pm 0,17$ \\
\hline $\begin{array}{l}\text { Масова частка відновлювальних сахарів } \\
\text { (до безводної речовини), \%, не менше }\end{array}$ & 70,0 & $83,65 \pm 1,2$ & $80,45 \pm 0,89$ & $80,21 \pm 0,92$ \\
\hline $\begin{array}{l}\text { Діастазне число (до безводної речовини), } \\
\text { од. Готе, не менше }\end{array}$ & 10,0 & $13,72 \pm 1,25$ & $16,95 \pm 2,05$ & $14,64 \pm 1,38$ \\
\hline $\begin{array}{l}\text { Кислотність, міліеквіваленти гідроокису } \\
\text { натрію }\left(0,1 \text { моль/дм }{ }^{3}\right) \text { на } 1 \text { кг, не більше }\end{array}$ & 50,0 & $22,5 \pm 0,71$ & $23,8 \pm 0,94$ & $21,9 \pm 1,03$ \\
\hline Якісна реакція на наявність паді & $\begin{array}{c}\text { Негативна або молочна- } \\
\text { біла каламуть }\end{array}$ & Негативна & Негативна & Негативна \\
\hline
\end{tabular}

За результатами визначення масової частки води у зразках меду встановлено, що залежно від виробника показник коливався в межах від $16,5 \pm 0,17 \%$ до $17,2 \pm 0,24 \%$, що відповідає вимогам стандарту для меду першого гатунку. Щодо вмісту інвертованого цукру, то у дослідних зразках меду його вміст становив від 80,21 \pm 0,92 до 83,65 $\pm 1,2 \%$, що свідчить про його доброякісність і дає змогу зарахувати цей мед до вищого гатунку. За результатами визначення діастазного числа встановлено, що у всіх досліджених зразках меду показник відповідав вимогам стандарту і коливався від $13,72 \pm 1,25$ до $16,95 \pm 2,05$ од. Готе. Показник активної кислотності всіх досліджених зразків меду коливався в межах вимог стандарту: від $21,9 \pm 1,03$ до $23,8 \pm 0,94$ міліеквівалентів гідроокису натрію $\left(0,1\right.$ моль/дм $\left.{ }^{3}\right)$ на 1 кг.

Реакція на наявність паді у всіх досліджених зразках виявилась негативною. За результатами аналізу, в усіх дослідних зразках меду виявлено пилкові зерна, що є ознакою його натуральності.

Таким чином, аналіз результатів досліджень фізико-хімічних показників меду встановив, що всі дослідні зразки, незалежно від виробника, відповідають вимогам ДСТУ 4497:2005.

На четвертому етапі наших досліджень визначали радіологічні показники соняшникового меду. За результатами оцінки встановлено, що вміст ${ }^{137} \mathrm{Cs}$ у дослідних зразках коливався в межах від 1,3 $\pm 0,23$ до $2,7 \pm 0,52$ Бк/кг, що не перевищує допустимих рівнів. Щодо ${ }^{90} \mathrm{Sr}$, то дослідженям виявлено слідові кількості.

\section{Обговорення}

За результатами аналізу відповідності маркування дослідних зразків меду натурального соняшникового до чинної нормативно-правової бази виявлено, що етикетки всіх зразків містили інформацію згідно зі ст. 6 (ст. 23.) Закону України "Про інформацію для споживачів щодо харчових продуктів”, але на всіх етикетках досліджених зразків встановлено порушення вимог маркування згідно 3 ДСТУ 4497:2005.

За результатами досліджень встановлено, що за органолептичними показниками всі досліджені зразки відповідали вимогам ДСТУ 4497:2005 "Мед натуральний. Технічні умови”, що узгоджуються з результатами органолептичної оцінки меду інших дослідників (Ljasota et al., 2019; Korbych, 2020; Kravchuk, 2021; De Beer et al., 2021).

Однак органолептична оцінка $є$ доволі простим методом оцінювання, що не може гарантувати якість харчового продукту. Натомість показники фізикохімічного складу надають об'єктивні дані щодо якості меду (Piven, 2019; Tyshkivs'ka \& Fedorov, 2018; Shtangret et al., 2020; Ling Chin \& Sowndhararajan, 2020).

Нами встановлено, що всі досліджені зразки соняшникового меду різних виробників відповідають вимогам ДСТУ 4497:2005, що узгоджується з результатами досліджень багатьох науковців (Morozova, 2017; Petryk et al., 2019; Piven et al., 2020; Tarasjuk \& Sljusarenko, 2021). 
Щодо показників безпечності, то згідно з отриманими нами результатами, всі досліджені зразки меду визнано безпечними за радіологічними показниками, що узгоджується 3 висновками щодо відповідності меду до вимог нормативних документів ряду інших дослідників (Piven, 2019; Fakhlaei et al., 2020).

Таким чином, аналізуючи результати проведених нами та іншими науковцями досліджень, ми вважаємо, що проблема відповідності показників якості й безпечності меду бджолиного натурального, що реалізується у торговельній мережі, вимогам національних стандартів потребує постійного моніторингу.

\section{Висновки}

1. За результатами досліджень маркування встановлено, що всі досліджені зразки соняшникового меду не містять окремої споживчої інформації, передбаченої ДСТУ 4497:2005, але відповідають вимогам Закону України “Про інформацію для споживачів щодо харчових продуктів".

2. За результатами визначення органолептичних та фізико-хімічних показників встановлено, що всі дослідні зразки відповідали вимогам ДСТУ 4497:2005.

3. За результатами визначення радіонуклідів встановлено, що всі зразки відповідали вимогам державного гігієнічного нормативу “Допустимі рівні вмісту радіонуклідів ${ }^{137} \mathrm{Cs}$ та ${ }^{90} \mathrm{Sr}$ у продуктах харчування та питній воді".

\section{Відомості про конфлікт інтересів}

Автори стверджують про відсутність конфлікту інтересів.

\section{References}

Blanc, S., Zanchini, R., Di Vita, G., \& Brun, F. (2021). The role of intrinsic and extrinsic characteristics of honey for Italian millennial consumers. British Food Journal, 123(6), 2183-2198. doi: 10.1108/BFJ-07-2020-0622.

Bonerba, E., Panseri, S., Arioli, F., Nobile, M., Terio, V., Di Cesare, F., Tantillo, G., \& Chiesa, L. M. (2021). Determination of antibiotic residues in honey in relation to different potential sources and relevance for food inspection. Food Chemistry, 334, 127575. doi: 10.1016/j.foodchem.2020.127575.

De Beer, T., Otto, M., Pretoruis, B., \& Schönfeldt, H. C. (2020). Monitoring the quality of honey: South African case study. Food Chemistry, 334, 128527. doi: 10.1016/j.foodchem.2020.128527.

Dudar, T. (2020). Rozvytok bdzhil'nyctva v Ukrai'ni: dosjagnuti uspihy, neobhidnist' marketyngovoi' kooperacii' v galuzi, strategija medovogo biznesu. Visnyk Ternopil's'kogo nacional'nogo ekonomichnogo universytetu, 2(96), 36-49. doi: 10.35774/visnyk2020. 02.036 (in Ukrainian).

Elamine, Y., Aazza, S., Lyoussi, B., Dulce Antunes, M., Estevinho, L. M., Anjos, O., Resende, M., Leonor Faleiro, M. \& Graça Miguel, M. (2017). Preliminary characterization of a Moroccan honey with a predominance of Bupleurum spinosum pollen. Journal of Apicultural Research, 57(1), 153-165. doi: 10.1080/00218839.2016.1265759.

Fakhlaei, R., Selamat, J., Khatib, A., Razis, A. F. A., Sukor, R., Ahmad, S., \& Babadi, A. A. (2020). The Toxic Impact of Honey Adulteration: A Review. Foods, 9(11), 1538. doi: 10.3390/foods9111538.

Golda, A. A., \& Jefimov, V. G. (2019). Osoblyvosti fizykohimichnyh pokaznykiv medu bdzholynogo zalezhno vid botanichnogo pohodzhennja. Materialy IV Mizhnarodnoi' naukovo-praktychnoi' konferencii' vykladachiv i studentiv "Aktual'ni aspekty biologii' tvaryn, veterynarnoi' medycyny ta veterynarno-sanitarnoi' ekspertyzy" (22-23 travnja 2019, Dnipro), 111-112. URL: http://biosafetycenter.com/iv-міжнародна-науково-практична-конфер/ (in Ukrainian),

Khimych, M. S., Piven', O. T., Palij, A. V., \& Kravchenko, V. P. (2018). Analiz jakisnyh pokaznykiv medu. Problemy zooinzhenerii' ta veterynarnoi' medycyny, 35(2), 97-101. URL: http://lib.osau.edu.ua/jspui/handle/123456789/2568 (in Ukrainian).

Korbych, N. M. (2020). Med - natural'nist' ta fal'syfikacija. Naukovo-informacijnyj visnyk. Zbirnyk informacijnyh povidomlen', stattej, dopovidej i tez naukovo-praktychnyh konferencij vykladachiv, aspirantiv, magistriv, studentiv, 13, 473-476. URL: http://dspace.ksau.kherson.ua/bitstream/handle/12345 6789/5491/Корбич_Херсон_11.09.20.ст.pdf?sequenc $\mathrm{e}=1$ \&isAllowed=y (in Ukrainian).

Kravchenko, M. V., \& Izhboldina, O. O. (2019). Osnovni tehnologichni zasoby, shho vykorystovujut'sja v agrarnomu sektori pry otrymani tovarnogo medu na pasikah. Agrarna nauka ta harchovi tehnologii', 4(107), 62-69 (in Ukrainian).

Kravchuk, O. (2021). Med i yoho yakist. Norwegian Journal of Development of the International Science, 55(2), 3-7. URL: http://www.norwegian-journal.com/wpcontent/uploads/2021/02/NJD_55_2.pdf (in Ukrainian).

Lazareva, L. N., Postoenko, V. O., \& Shtangret, L. I. (2021). Ocenka kachestva meda na torgovyh rynkah Kieva. Materialy Mezhdunarodnoj nauchnoprakticheskoj konferencii, provodimoj pod jegidoj Federacii pchelovodcheskoj organizacij "Apislavija" "Aktual'nye voprosy sovremennogo pchelovodstva" (20-22 maja 2021, Minsk), 55-58. URL: http://www.belsad.by/site/images/Congress\%20bee/A PISLAVIA_BEE.pdf (in Russian).

Lazarjeva, L. M., Postojenko, V. O., Shtangret, L. I., \& Postojenko, G. V. (2021). Skryning jakosti lypovogo medu z riznyh regioniv Ukrai'ny. Visnyk agrarnoi' nauky, 8(821), 26-31. doi: 10.31073/agrovisnyk202108-03 (in Ukrainian).

Ling Chin, N., \& Sowndhararajan, K. (2020). A Review on Analytical Methods for Honey Classification, Identification and Authentication. Honey Analysis New Advances and Challenges, 1-33. doi: 10.5772/intechopen.90232.

Ljasota, V. P., Bogatko, N. M., Bukalova, N. V., Bogatko, L. M., \& Kolodka, A. V. (2019). Sanitarno- 
gigienicheskaja ocenka meda po pokazateljam kachestva i bezopasnosti. Aktual'nye problemy intensivnogo razvitija zhivotnovodstva. UO Belorusskaja gosudarstvennaja ordenov oktjabr'skoj revoljucii i trudovogo krasnogo znameni sel'skohozjajstvennaja akademija (22-24 maja 2019, Gorki), 2, 179-185. URL: http://rep.btsau.edu.ua/handle/BNAU/3210 (in Russian)

Morozova, O. V. (2017). Modelirovanie kolichestvennogo ocenivanija riskov v sisteme kontrolja kachestva pchelinogo meda na osnove standarta HASSP. Polzunovskij vestnik, 4, 9-13. URL: https://cyberleninka.ru/article/n/modelirovaniekolichestvennogo-otsenivaniya-riskov-v-sistemekontrolya-kachestva-pchelinogo-meda-na-osnovestandarta-hassp/viewer (in Russian).

Petryk, A. S., Jakubchak, O. M., \& Galaburda, M. A. (2019). Bezpechnist' ta jakist' medu natural'nogo. Materialy Mizhnarodnoi' naukovo-praktychnoi' konferencii' magistrantiv “Aktual'ni problemy veterynarnoi' medycyny" (21 lystopada 2019 r., Bila cerkva), 39-40 (in Ukrainian).

Piven, O. T. (2019). Monitoryng fizyko-himichnyh pokaznykiv medu, shho realizujet'sja u BilgorodDnistrovs'komu rajoni Odes'koi' oblasti. Agrarnyj vistnyk Prychornomor'ja, 93, 195-198 URL: https://abbsl.osau.edu.ua/index.php/visnuk/issue/view/ 8/93-2019 (in Ukrainian).

Piven, O. T., Khimych, M. S., Salata, V. Z., Gutyj, B. V., Naidich, O. V., Skrypka, H. A., Koreneva, Z. B., Dvylyuk, I. V., Gorobey, O. M., \& Rud, V. O. (2020). Contamination of heavy metals and radionuclides in the honey with different production origin. Ukrainian Journal of Ecology, 10(2), 405-409. doi: 10.15421/2020 117.

Postojenko, V. O., Lazarjeva, L. M., \& Jaremchuk, O. S. (2019). Osnovni pokaznyky ocinky jakosti i bezpechnosti medu bdzholynogo v Ukrai'ni ta i'h garmonizacija z vymogamy JeS. Wschodnioeuropejskie Czasopismo Naukowe. East European Scientific Journal. Warsaw, Poland, 12(52), 14-21 (in Ukrainian).
Pro zatverdzhennja Derzhavnyh gigijenichnyh normatyviv «Dopustymi rivni vmistu radionuklidiv 137Cs ta $90 \mathrm{Sr}$ u produktah harchuvannja ta pytnij vodi». Nakaz MOZ Ukrai'ny № 256 vid 3 travnja 2006 r. [potochna redakcija vid 15.07.2008] https://zakon.rada.gov.ua/laws/show/z0845-06\#Text (in Ukrainian).

Ratiu, I. A., Al-Suod, H., Bukowska, M., Ligor, M., \& Buszewski, B. (2020). Correlation Study of Honey Regarding their Physicochemical Properties and Sugars and Cyclitols Content. Molecules, 25(1), 34. doi: 10.3390/molecules25010034.

Shtangret, L., Lazarjeva, L., Shapoval, Zh., \& Koval', O. (2020). Fizyko-himichni pokaznyky bdzholynogo medu tryvalogo zberigannja. Naukovo-vyrobnychyj zhurnal "Bdzhil'nyctvo ukrai'ny", 1(5). doi: 10.46913/beekeepingjournal.2020.5.06 (in Ukrainian).

Tarasjuk, I. A., \& Sljusarenko, A. O. (2021). Vymogy do pokaznykiv bezpeky medu natural'nogo. Materialy Mizhnarodnoi' naukovo-praktychnoi' konferencii' studentiv "Naukovi poshuky molodi u HHI stolitti. Novitni tehnologii' vyrobnyctva ta pererobky produkcii' tvarynnyctva" (14 kvitnja 2021 roku, Bila Cerkva), 9296. URL: https://science.btsau.edu.ua/sites/default/ files/tezy/btf_stud_tezy_14.04.21.pdf (in Ukrainian).

Tyshkivs'ka, N. V., \& Fedorov, O. O. (2018). Analiz pokaznykiv jakosti medu. Materialy Mizhnarodnoi' naukovo-praktychnoi' konferencii' magistrantiv "Aktual'ni problemy veterynarnoi' medycyny" (22 lystopada 2018r., Bila Cerkva), 51-53. URL: https://science.btsau.edu.ua/sites/default/files/tezy/tez y_vet_magistri_2018.pdf (in Ukrainian).

Vishchur, V. Y., Gutyj, B. V., Nischemenko, N. P., Kushnir, I. M., Salata, V. Z., Tarasenko, L. O., Khimych, M. S., Kushnir, V. I., Kalyn, B. M., Magrelo, N. V., Boiko, P. K., Kolotnytskyy, V. A., Velesyk, T., Pundyak, T. O., Gubash, O. P. (2019). Effect of industry on the content of fatty acids in the tissues of the honey-bee head. Ukrainian Journal of Ecology, 9(3), 174-179. doi: 10.15421/2019_76. 